\title{
RESEARCH NOTE \\ Effect of an infusion of canelo and bitter lupin on Aegorhinus superciliosus adults
}

\author{
Romina Quintana, Alexis Palma, Ramón Rebolledo, and Alfonso Aguilera \\ Laboratorio de Entomología Aplicada. Facultad de Ciencias Agropecuarias y Forestales. Universidad de La \\ Frontera. Casilla 54-D. Temuco, Chile.
}

\begin{abstract}
R. Quintana, A. Palma, R. Rebolledo, and A. Aguilera. 2011. Effect of an infusion of canelo and bitter lupin on Aegorhinus superciliosus adults. Cien. Inv. Agr. 38(3): 397-403. $A$. superciliosus (Coleoptera: Curculionidae), known as "cabrito del maitén" (CM) among other names, is an important pest affecting fruit-bearing bushes in southern and central southern Chile. One means of control is the use of organically synthesized insecticides that target the adult, the application of which generally is disadvantageous because these insecticides have long-lasting residual effects and because spraying coincides with flowering and the harvest of the fruit. To complement other pesticides that are more degradable and selective and less harmful to the environment, this work studied the effect of an infusion of canelo buds (Drimys winteri) with leaves and stems of bitter lupin (Lupinus albus) on CM adults. The research evaluated mortality, anti-feeding effect and the percentage of eggs hatched with four treatments using these plants at concentrations of 10,20, 40 and 100\% infusion, plus a control with no application. Each treatment was replicated ten times. The infusions obtained at a proportion of $1: 1(\mathrm{w} / \mathrm{v})$ exhibited no effect on the variables studied at a significance of $5 \%$, with the exception of its effect on egg hatching, which exhibited an apparent direct relation with the canelo infusion and an inverse relation with the aqueous extract of lupin. The results indicate that the lupin infusion may have an insectistatic effect on the reproduction of CM.
\end{abstract}

Key words: Aegorhinus superciliosus, aqueous extract, Drimys winteri, Lupinus albus.

\section{Introduction}

Berries, such as blueberries, raspberries and strawberries, are important fruit crops in central southern Chile, and the production of these berries is mainly for export (Devotto and Gerding, 2001; Kong, 2009).

Growth in production is not only supported by business opportunities for farmers but also by

Received June 8, 2010. Accepted April 20, 2011.

Corresponding author: ramonr@ufro.cl the growing demand of consumers, regardless of these berries being more expensive products (ODEPA, 2008; Morales and Labra, 2009).

The aforementioned fact has favored the expansion of berry cultivation in Chile, but at the same time, root feeder pests affecting these fruit-bearing bushes have become a significant problem (Devotto and Gerding, 2001), with "burrito" or "cabrito del maitén" (Aegorhinus superciliosus, shortened as $\mathrm{CM}$ ) being one of the most important during two life stages, affecting the host at the stem and root 
levels as larvae, which may cause the death of the plant, and causing damage to the buds and fruits as adults (Parra et al., 2009).

One method to control this insect is based on the use of synthetic insecticides, which are fast acting, easy to use and permanently available in the market (Parra et al., 2009; SAG, 2009). However, applying these products has negative consequences, especially when the use of these products is focused on the adult stage. Among the inconveniences are the long residual effect, the exclusion period and the toxic effect on pollinating agents when these pesticides are applied near the time of flowering (Mutis et al., 2009; Parra et al., 2009).

Because of the flaws in traditional synthetic insecticides, agrochemical companies have been progressively changing their development plans, moving away from broad-spectrum and long persistence insecticides that are able to control many pest species simultaneously and require few applications to products with greater selectivity and a shorter period of persistence in the environment (Fuentes, 2003; Silva et al., 2002). Therefore, insecticides and insectistatics of vegetal origin have arisen again as one of the least risky and most sustainable options for phytoprotection after being displaced by inorganic insecticides and subsequently by organic insecticides (Rodríguez et al., 2003; Murray, 2006).

Canelo (Drimys winteri) is a native species in Chile with medicinal properties. This plant contains many drimanes in the leaves and bark, including polygodial, to which an important antifeedant effect is attributed for different insect species that are considered pests (Spurr and McGregor, 2003; Zapata et al., 2009; Zapata et al., 2010). Bitter lupin, Lupinus albus, is a legume cultivated in southern Chile by small farmers and exported to Europe and the Middle East for human consumption (Mera and Galdames, 2007). This species contains different quinolizidine alkaloids that play a defensive role against predators of this plant (Chevalier et al., 2000).
We hypothesized that an infusion of canelo buds and bitter lupin could control the adult stage of $\mathrm{CM}$. The objectives of this study were to evaluate the effect of an infusion of canelo buds and of the leaves and stems of bitter lupin on CM adults. We assessed the effect of this infusion on mortality, feeding and the hatching of eggs.

\section{Materials and methods}

The biotests were conducted between November 2008 and January 2009 under semi-controlled conditions in a laboratory in the Applied Entomology Laboratory of the Facultad de Ciencias Agropecuarias y Forestales, Universidad de La Frontera, located in Temuco, Region of La Araucanía, Chile (Lat. $38^{\circ} 45^{\prime} \mathrm{S}$; Long. $72^{\circ} 37^{\prime} \mathrm{W}$ ). The tests were carried out at $22 \pm 2{ }^{\circ} \mathrm{C}$ with a relative humidity of $57 \pm 3 \%$ and a photoperiod of 18 hours light and 8 hours dark.

Six hundred adult CM specimens were collected during the first two weeks of November 2008 from commercial blueberry plantations at kilometer 2.5 along the Freire-Villarrica route (Lat. $38^{\circ} 57^{`} \mathrm{~S}$; Long. $\left.72^{\circ} 35^{\prime} \mathrm{W}\right)$. The insects were randomly arranged in two cardboard boxes (300 insects in each) and maintained in a refrigerator at a temperature of $5{ }^{\circ} \mathrm{C}$ with blueberry twigs until the tests were carried out.

The canelo buds were collected from secondary forests located in Hijuela Santa Carolina at km 24 along the Lautaro-Curacautín route, whereas the leaves and stems of bitter lupin Boroa-INIA were collected from the El Roble farm in the commune of Freire (Lat. $38^{\circ} 57^{\prime} \mathrm{S}$; Long. $72^{\circ} 37^{\prime} \mathrm{W}$ ). Both species were collected in early November 2008.

Bramble leaves (Rubus ulmifolius), used for feeding CM adults during the evaluations, were collected from a bush close to the site of research, and blueberry leaves, cv. Bluegold, were collected from the El Tirol plot (Lat. $38^{\circ} 45^{`} \mathrm{~S}$; Long. $72^{\circ}$ $\left.39^{\prime} \mathrm{W}\right)$. The leaves were completely expanded and not senescent. 
The canelo infusion was prepared 24 hours after collecting the shoots, during which time they were refrigerated according to the methodology proposed by Aguilera (Alfonso Aguilera, 2008, Ingeniero Agrónomo, Departamento de Producción Agropecuaria, Facultad de Ciencias Agropecuarias y Forestales, Universidad de La Frontera, Temuco, Chile. Personal communication) one kilogram of chopped shoots approximately $1 \mathrm{~cm}$. was used and placed in a stainless steel pan with one liter of boiled distilled water. This mixture was left to rest for $24 \mathrm{~h}$ with shaking from time to time, and then filtered to obtain approximately $1,050 \mathrm{~mL}$ of infusion.

The same procedure was used for the lupin infusion, using one kilogram of green matter composed of leaves and stems, but this preparation was left to rest for 10 hours, and then filtered to obtain $1,000 \mathrm{~mL}$ of aqueous extract. Both filtered infusions were separately preserved in plastic bottles wrapped with aluminum foil at $6{ }^{\circ} \mathrm{C}$.

\section{Mortality}

The insects were subjected to a 48-hour-fast and then randomly distributed in groups of five CM adults kept in 100 transparent plastic boxes and fed bramble leaflets moistened with one of the infusions, which were obtained by diluting the stock infusions with distilled water (Table 1). Each treatment had ten replicates, and the insects were observed for five days, including the control without the application of any solution.

Table 1. Infusion treatments of canelo and bitter lupin.

\begin{tabular}{ll}
\hline Treatments $^{1}$ & Solutions \\
\hline $\mathrm{T}_{0}$ & Control \\
$\mathrm{T}_{1}$ & $10 \mathrm{~mL} \mathrm{II}+90 \mathrm{~mL} \mathrm{DW}$ \\
$\mathrm{T}_{2}$ & $20 \mathrm{~mL} \mathrm{II}+80 \mathrm{~mL} \mathrm{DW}$ \\
$\mathrm{T}_{3}$ & $40 \mathrm{~mL} \mathrm{II}+60 \mathrm{~mL} \mathrm{DW}$ \\
$\mathrm{T}_{4}$ & Alone II \\
\hline
\end{tabular}

II: Initial infusion; DW: Distilled water. ${ }^{1}$ Each treatment with ten replicates.
The dead insects were counted and withdrawn on a daily basis to quantify the biocide action of the infusions, and the degree of efficiency was evaluated using the Abbott formula (Casals, 2003).

\section{Anti-feeding effect}

Fifty blueberry leaves per type of aqueous extract were photocopied and then distributed, moistened with the appropriate infusion as described in Table 1 but with only one insect per experimental unit. After 48 hours, the blueberry leaves were withdrawn and photocopied again, and the anti-feeding effect on the $\mathrm{CM}$ was evaluated using the differences and estimates using the program ZWCAD 2009 (Procad Ltda., Santiago, Chile, 2008). The areas consumed for each type of infusion were subject to one-way analysis of variance and Tukey's multiple comparison test (5\%). All statistical analyses were performed using R and R-Commander in Spanish (Universidad de Cádiz, Cádiz, Spain, 2009).

\section{Effect on the percentage of eggs hatched}

The eggs laid were collected during the mortality test and during the following week, when the insects were fed untreated bramble to determine if the infusions of canelo and bitter lupin had a secondary effect.

The eggs were arranged individually on filter paper moistened with distilled water in five Petri plates, according to the treatment, and the paper was kept constantly moist. The hatched eggs were counted for 30 days by counting the number of first instar larva. These numbers were subsequently transformed into percentages with respect to the total number of eggs laid per treatment and then subject to statistical analysis.

\section{Results}

The infusions of canelo and bitter lupin did not have any effect on mortality; an equal or higher 
Table 2. Mortality of CM adults (\%) by treatment and type of infusion after five days.

\begin{tabular}{ccc}
\hline & \multicolumn{2}{c}{ Mortality (\%) } \\
\cline { 2 - 3 } Treatment & Canelo & Bitter lupin \\
\hline $\mathrm{T}_{0}$ & 4 & 14 \\
$\mathrm{~T}_{1}$ & 0 & 12 \\
$\mathrm{~T}_{2}$ & 2 & 4 \\
$\mathrm{~T}_{3}$ & 0 & 12 \\
$\mathrm{~T}_{4}$ & 4 & 6 \\
\hline
\end{tabular}

level of natural death occurred in the control group relative to the other treatments (Table 2).

The infusions did not have any significant effect on the percentage of consumption with respect to the control (Figure 1). However, the percentage of hatched eggs per treatment with the canelo infusion exhibited a direct relationship between the dose applied and the number of eggs hatched, whereas the lupin infusion resulted in a diminished hatching as the dose was increased (Figure 2).

\section{Discussion}

\section{Mortality}

The lack of biocide activity of the infusions during the five-day test could be due to different reasons; one reason may be the slow action of the active in-

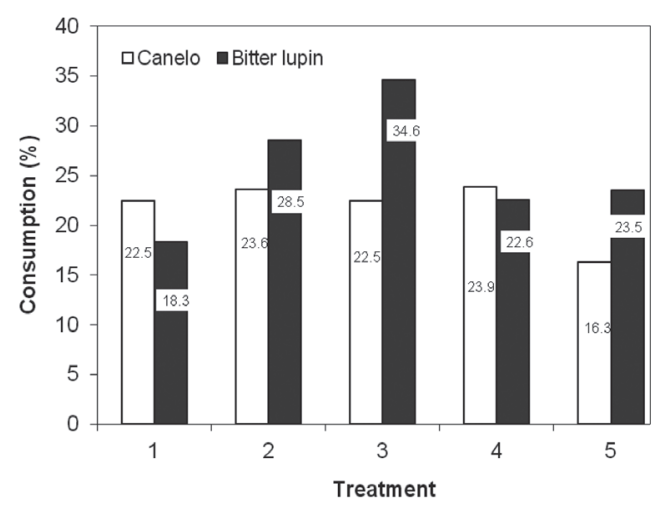

Figure 1. Average consumption (\%) of the leaf area by CM by treatment and type of infusion. The same letter indicates that there was no significant difference between samples at a significance level of $5 \%$. gredients contained in the aqueous extracts, which might affect other physiological functions before the insect dies. This hypothesis is consistent with the results of Bertrand et al. (2007), who indicated that an immediate action was not necessarily observed with the plant extracts because there is supposed to be a balance in the system. Additionally, it has been reported that most species of plants used for vegetal protection exhibit an insectistatic effect rather than an insecticidal effect; that is, they inhibit the normal development of the insects (Silva et al., 2002; Rodríguez et al., 2003; Tinzaara et al., 2006).

The 1:1 proportion (1 $\mathrm{kg}$ of vegetal material:1 L of distilled water) at which the infusions were prepared might have influenced the results because this proportion probably did not favor the net movement of the active principles from the plants into the water; likewise, a marked concentration gradient was not generated due to the absence of a higher volume of solvent with respect to the vegetal material, (Salisbury and Ross, 2000). Similarly, it has been observed that $100 \mathrm{~g}$ of fresh plants is used per liter of water in the preparation of botanic extracts because a more concentrated or effective extract is not obtained if the relative amount of vegetal material is increased (Pérez and Iannacone, 2006; Bertrand et al., 2007). The results of this research on lupin and canelo confirm the information mentioned above.

The extraction procedure could influence the amounts of the active components in the final extract and

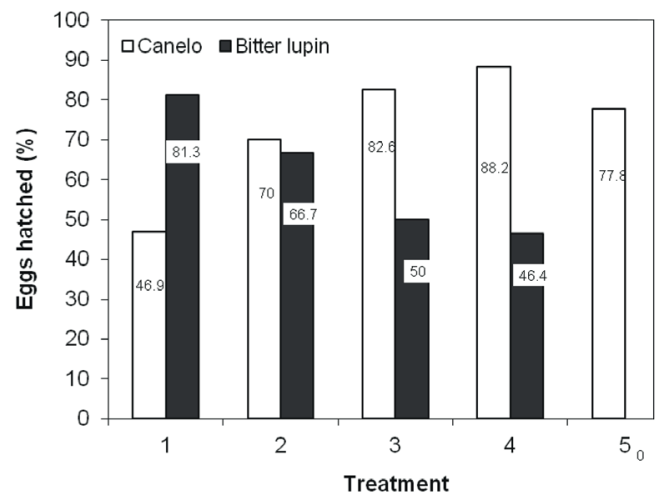

Figure 2. Percentage of eggs hatched with respect to the number of eggs laid by treatment and type of infusion. 
therefore, the effect on of these extracts insects. In this regard, Iannacone and Lamas (2003) and Guzzo et al. (2006) state that the extracts obtained with organic solvents exhibit more activity than the respective aqueous extracts. Additionally, the content of the active components in the plants is variable due to environmental factors, the stage of development and storage, among other factors (Sánchez et al., 2005; Muñoz et al., 2007; Chludil et al., 2009).

\section{Anti-feeding effect}

In spite of the known anti-feeding effect of the drimanos isolated from canelo, polygodial, in particular (Messchendorp et al., 1998; Spurr and McGregor, 2003; Zapata et al., 2009; Zapata et al., 2010), and the defensive functions of the quinolizine alkaloids in different lupin species (Bermúdez et al., 2009), significant differences were not observed relative to the control, probably due to the reasons previously mentioned above regarding the extraction of the active components.

Nevertheless, it is extremely difficult to compare the power of a specific anti-feeding effect in different insects because the effect will be more effective in some species than in others (Spurr and McGregor, 2003; Tinzaara et al., 2006).

\section{Effect on the percentage of eggs hatched}

The results obtained with the canelo infusion may be due to the stimulation of embryogenesis by the product, resulting in hatching. However, this represents a negative response with respect to the aim of this study, which was intended to identify a method by which to control CM.

In the case of the lupin infusion, the decreasing frequency of hatching could have occurred because the extract affected some stage of reproduction, which is consistent with the suggestion of Aguilera et al. (2009), who concluded that azadirachtin has an effect that alters the laying and embryogenesis of A. superciliosus. Therefore, fecundity and fertility may be affected by secondary compounds from the plants studied that exert an insectistatic effect (Rodríguez et al., 2003).

In conclusion, the infusion of canelo and bitter lupin at a ratio of 1:1 (p:v) does not exert any effect relevant to the control of CM; no relation was observed between the dose applied and the response of any studied variable except for the percentage of hatched eggs, which showed a direct relation between the concentrations and the number of larvae that emerged with the canelo infusion. On the other hand, an inverse tendency was observed with the lupin extract.

Therefore, the canelo infusion at the indicated proportion should be discarded as a measure of the control for adult CM, and the possible insectistatic effect on reproduction of the bitter lupin infusion should be analyzed to determine if this plant can be used for the control of CM.

\section{Acknowledgments}

We thank project DIUFRO DI10-101 of Universidad de La Frontera for the financing and the vegetable garden of San Judas Tadeo of Exportadora Patagonia Food S.A. for their support. 


\title{
Resumen
}

\begin{abstract}
R. Quintana, A. Palma, R. Rebolledo y A. Aguilera. 2011. Efecto de la infusión de canelo y lupino amargo sobre el adulto de Aegorhinus superciliosus. Cien. Inv. Agr. 38(3): 397403. A. superciliosus (Coleoptera: CurculionidaeI), denominado como cabrito del maitén (CM), entre otras, es una importante plaga que afecta al complejo de los frutales arbustivos en la zona centrosur y sur de Chile. Una parte de su control está orientado al adulto con insecticidas de síntesis orgánica, cuyas aplicaciones por lo general, tienen el inconveniente de presentar un largo efecto residual y coincidir su aspersión con la floración y la cosecha de frutos. A fin de complementar los plaguicidas sintéticos con otros más degradables, selectivos y menos dañinos para el ambiente, se estudió el efecto de la infusión de brotes de canelo (Drimys winteri) y de hojas-tallos de lupino amargo (Lupinus albus) sobre el adulto del CM completamente al azar. Esta investigación evaluó la mortalidad, la actividad antialimentaria y el porcentaje de eclosión de huevos con cuatro tratamientos con las respectivas plantas en concentraciones de 10, 20, 40 y $100 \%$ de infusión más un testigo sin aplicación. Los tratamientos tuvieron diez repeticiones cada uno. Las infusiones obtenidas en la proporción 1:1 (p/v) presentaron una nula acción sobre las variables estudiadas a una significancia del 5\%, con excepción del efecto sobre la eclosión de huevos que mostró una aparente relación directa con la infusión de canelo y una tendencia inversa con el extracto acuoso de lupino. Los resultados indicaron la posibilidad que la infusión de lupino tenga efecto insectistático en la reproducción del CM.
\end{abstract}

Palabras clave: Aegorhinus superciliosus, Drimys winteri, extracto acuoso, Lupinus albus.

\section{References}

Aguilera, A., M. Zampezzi, X. Araneda, C. Klein, and R. Rebolledo. 2009. Efectividad de la azadirachtina en la inhibición de la embriogénesis de Aegorhinus superciliosus (Guérin) (Coleoptera: Curculionidae). Idesia 27:47-55.

Bermúdez, K., J. Martínez, R. Figueroa, M. Wink, and L. Legal. 2009. Activity of quinolizidine alkaloids from three Mexican Lupinus against the lepidopteran crop pest Spodoptera frugiperda. BioControl 54:459-466.

Bertrand, B., J.P. Collaert, and E. Petiot. 2007. Plantas para curar plantas: tratar sin química los problemas del huerto y el jardín. Rosa Barasoain. La Fertilidad de la Tierra Ediciones. Estella, España. 107 pp.

Casals, P. 2003. Evaluación de insecticidas en campo. In: Silva, G. and R. Hepp (eds.). Bases para el manejo racional de insecticidas. Universidad de Concepción. Fundación para la Innovación Agraria (FIA). Chillán, Chile. p. 175-202.

Chevalier, L., C. Desbuquois, J. Papineau, and M. Charrier. 2000. Influence of the quinolizidine alkaloid content of Lupinus albus (Fabaceae) on the feeding choice of Helix aspersa (Gastropoda: Pulmonata). Journal Molluscan Studies 66:61-68.
Chludil, H., M. Vilariño, M. Franco, and S. Leicach. 2009. Changes in Lupinus albus and Lupinus angustifolius alkaloid profiles in response to mechanical damage. Journal of Agricultural and Food Chemistry 57:6107-6113.

Devotto, L., and M. Gerding. 2001. Plagas de los berries en la zona centro sur. Tierra Adentro (Chile) 36:12-14.

Fuentes, E. 2003. Los insecticidas en la agricultura del nuevo siglo. In: Silva, G. and R. Hepp (eds.). Bases para el manejo racional de insecticidas. Universidad de Concepción. Fundación para la Innovación Agraria (FIA). Chillán, Chile. p. 291-307.

Guzzo, E.C., M.A.G.C. Tavares, and J.D. Vendramin. 2006. Evaluation of insecticidal activity of aqueous extracts of Chenopodium spp. in relation to Rhyzopertha dominica (Fabr.) (Coleoptera: Bostrichidae). p. 926-930. In: I. Lorini et al. (eds.). $9^{\text {th }}$ International Working Conference on Stored Product Protection. Campinas, São Paulo, Brazil. Available online to: http://bru.gmprc.ksu.edu/proj/iwcspp/iwcspp9. html (Website accessed: March 12, 2010).

Iannacone, J., and G. Lamas. 2003. Efectos toxicológicos de extractos de molle (Schinus molle) y lantana (Lantana camara) sobre Chrysoperla externa (Neuroptera: Chrysopidae), Trichogram- 
ma pintoi (Hymenoptera: Tricrogrammatidae) y Copidosoma koehleri (Hymenoptera: Encyrtidae) en el Perú. Agricultura Técnica 63:347-360.

Kong, J. 2009. Análisis económico del rubro berries. Consorcio Tecnológico de la Fruta. INIA-Raihuén. Available online to: http://www.centrotecnologicoberriesdelmaule.cl/documentos/1.pdf (Website accessed: March 16, 2010).

Mera, M., and R. Galdames. 2007. Boroa-INIA, primera variedad de lupino (Lupinus albus) amargo exportable obtenida en Chile. Agricultura Técnica 67:320-324.

Messchendorp, L., G.J.Z. Gols, and J.J.A. van Loon. 1998. Behavioral effects and sensory detection of drimane deterrents in Myzus persicae and Aphis gossypii nymphs. Journal of Chemical Ecology 24: 1433-1446.

Morales, C., and E. Labra. 2009. Berries orgánicos alternativa para la diversidad productiva del rubro. Informativo INIA Raihuen $\mathrm{N}^{\circ} 33.4$ p. Instituto de Investigaciones Agropecuarias (INIA). Available online at: http://www.inia.cl/link.cgi/ Raihuen/ (Website accessed: October 4, 2009).

Muñoz, D., H. Vogel, R. Yunes, I. Razmilic, L. Bresciani, and A. Malheiros. 2007. Presence of polygodial and drimenol in Drimys populations from Chile. Biochemical Systematics and Ecology 35:434-438.

Murray, I. 2006. Botanical insecticidas, deterrents, and repellents in modern agricultura and an increasingly regulated world. Annual Review of Entomology 51:45-66.

Mutis, A., L. Parra, R. Palma, F. Pardo, F. Perich, and A. Quiroz. 2009. Evidence of contact pheromone use in mating behavior of the raspberry weevil (Coleoptera: Curculionidae). Environmental Entomology 38:192-197.

ODEPA. 2008. Dinámica productiva y comercial: Situación y perspectivas de los berries en Chile. Available online at: http://www.odepa.gob.cl/ odepaweb/publicaciones/doc/2122.pdf (Website accessed: October 10, 2009).

Parra, L., A. Mutis, A. Aguilera, R. Rebolledo, and A. Quiroz. 2009. Estado del conocimiento sobre el cabrito del frambueso (CF), Aegorhinus superciliosus (Guérin) (Coleoptera: Curculionidae). Idesia 27:57-65.

Pérez, D., and J. Iannacone. 2006. Efectividad de extractos botánicos de diez plantas sobre la mortalidad y repelencia de larvas de Rhynchophorus palmarum L., insecto plaga del pijuayo Bactris gasipaes Kunth en la amazonía del Perú. Agri- cultura Técnica 66:21-30.

Rodríguez, C., G. Silva, and J. Vendramin. 2003. Insecticidas de origen vegetal. In Silva, G. y R. Hepp. (eds.). Bases para el manejo racional de insecticidas. Universidad de Concepción. Fundación para la Innovación Agraria (FIA). Chillán, Chile. p. 87-112.

SAG. 2009. Lista de plaguicidas autorizados por el Servicio Agrícola y Ganadero: actualizados al 11 de septiembre de 2009. Available online at: http://www.sag.gob.cl (Website accessed: September 21, 2009).

Salisbury, F., and Ross, C. 2000. Fisiología de las plantas 1. Células: agua, soluciones y superficies. Internacional Thomson Editores Spain. Paraninfo. Madrid, España. 305 pp.

Sánchez, M., P. Altares, M. Pedrosa, C. Burbano, C. Cuadrado, C. Goyoaga, M. Muzquiz, C. Jiménez, and G. Dávila. 2005. Alkaloid variation during germination in different lupin species. Food Chemistry 90:347-355.

Silva, G., A. Lagunes, J. Rodríguez, and D. Rodríguez. 2002. Insecticidas vegetales: una vieja y nueva alternativa para el manejo de plagas. Manejo Integrado de Plagas y Agroecología 66:4-12.

Spurr, E.B., and P.G. McGregor. 2003. Potencial invertebrate antifeedants for toxic baits used for vertebrate pest control: a literature review. $36 \mathrm{p}$. Department of Conservation. Wellington, Nueva Zelanda. Available online at: http://www.doc. govt.nz/upload/documents/science-and- technical/sfc232.pdf (Website accessed: August 21, 2008).

Tinzaara, W., W. Tushemereirwe, C.K. Nankinga, C.S. Gold, and I. Kashaija. 2006. The potential of using botanical insecticides for the control of the banana weevil, Cosmopolites sordidus (Coleoptera: Curculionidea). African Journal of Biotechnology 5:1994-1998.

Zapata, N., F. Budia, E. Viñuela, and P. Medina. 2009. Antifeedant and growth inhibitory effects of extracts and drimanes of Drimys winteri stem bark against Spodoptera littoralis (Lep., Noctuidae). Industrial Crops and Products 30:119-125.

Zapata, N., M. Vargas, P. Medina, E. Viñuela, B. Rodríguez, and A. Fereres. 2010. The activity of a selected extract of Drimys winteribark and polygodial on settling and probing behaviour of the lettuce aphid Nasonovia ribisnigri. Available online at: http://www.springerlink.com/ content/9507r37r4m248400/ (Website accessed: March 16, 2010). 
